\title{
Quantitative determination of alliin in dried garlic cloves and products by high-performance thin-layer chromatography
}

\author{
Nasir A Siddiqui*, Ramzi A Mothana and Perwez Alam \\ Department of Pharmacognosy, College of Pharmacy, King Saud University, PO Box 2457, Riyadh 11451, Saudi Arabia
}

*For correspondence: Email: nsiddiqui@ksu.edu.sa; Fax: $00966114677245 ;$ Tel: 00966544016921

\begin{abstract}
Purpose: To standardize the garlic samples and its products for alliin contents. Methods: A direct high-performance thin-layer chromatographic (HPTLC) method was developed to determine alliin in Chinese (CG) and Indian garlic (IG) and two other marketed products from USA and UK, respectively. Scanning and quantification were performed at $205 \mathrm{~nm}$. Furthermore, chromatography was performed on pre-coated HPTLC plates with the solvent mixture, $n$ - hexane:ethyl acetate (29:1 $v / v)$, as the mobile phase. In addition, the parameters suggested by International Conference on Harmonization for analytical procedures were considered to validate the proposed method.

Results: The system gave a compact spot of alliin at $R F=0.19 \pm 0.01$ The linear regression data for the calibration plots showed a good linearity $\left(r^{2}=0.996\right)$ in the concentration range of $200-1600 \mathrm{ng}$. Linear regression equation was represented by $Y=1.792 x+182.855$, while $L O D$ and $L O Q$ values were 40.42 ngband $^{-1}$ and 111.72 ng.band $^{-1}$, respectively. The method showed excellent accuracy with recovery of $98.20-99.10 \%$ and good precision with RSD of $1-2.65 \%$.

Conclusion: The proposed method is selective, sensitive and accurate for the determination of alliin in garlic and its products. It is also evident from the results obtained that raw Indian garlic has higher alliin content than Chinese garlic.
\end{abstract}

Keywords: Garlic, HPTLC, Alliin, Hypercholesteremia, Quantification

Tropical Journal of Pharmaceutical Research is indexed by Science Citation Index (SciSearch), Scopus, International Pharmaceutical Abstract, Chemical Abstracts, Embase, Index Copernicus, EBSCO, African Index Medicus, JournalSeek, Journal Citation Reports/Science Edition, Directory of Open Access Journals (DOAJ), African Journal Online, Bioline International, Open-J-Gate and Pharmacy Abstracts

\section{INTRODUCTION}

Garlic (Allium sativum) is an important culinary and medicinal plant which possesses several biological activities such as antibiotic, antitumor, anti-atherosclerotic, cardioactive, etc. [1-4]. Alliin, chemically known as S-allyl cysteine sulfoxide (Fig. 1) is the major flavor precursor in garlic. In addition to alliin, some other compounds such as isoalliin, mithiin and a trace amount of propiin are also found in garlic [5]. Alliin is the most noticeable biomarker in garlic, consist of about 10 and $30 \mathrm{mg} / \mathrm{g}$ in fresh and dry garlic, respectively [6]. The daily intake of garlic in various forms recommended by WHO is $2-5 \mathrm{mg}$ of oil, $2-5 \mathrm{~g}$ of fresh garlic, $0.4-1.2 \mathrm{~g}$ of dry powdered garlic and $0.3-1 \mathrm{~g}$ of the dry extract [7]. As a dietary supplement, $600-900 \mathrm{mg}$ of garlic per day is suggested by the American Dietetic Association [8].

Allicin is the therapeutically useful compound of garlic. However, it is difficult to directly determine it due to its high reactivity and unstable nature. The range of the amount of allicin in garlic samples is reported by several authors from 3.37 
to $8.99 \mathrm{mg} / \mathrm{g}$ [9-11]. The quantity of alliin indicates the quality of garlic. Upon crushing of garlic cloves the enzyme alliinase get access to alliin and consequently alliin is converted into allicin with a release of characteristic aroma [12]. The reported ratio of conversion from alliin to allicin is $3: 1$ along with pyruvic acid, ammonia, and carbon dioxide as by-products [13].

Due to the lack of scientific data the World Health Organization (WHO) has given the emphasis for the evaluation of the effectiveness of plant-based drugs [14]. Several methods of analyses for alliin such as spectrophotometry [15], gas chromatography [16], capillary electrophoresis [17], spectrophotometric methods [18], high performance liquid chromatography [19] and high performance thin layer chromatography [20-22] have been proposed. In recent years, due to low operation cost and high sample throughput, HPTLC gained much acceptance for its analytical interventions in herbal drugs and formulations. [23]. The increasing demand for natural drugs motivated the authors to perform this study in order to provide an easier and sensitive tool for quality control units of herbalists. The validation of the proposed method was performed as per the International Conference on Harmonization (ICH) guidelines [24].

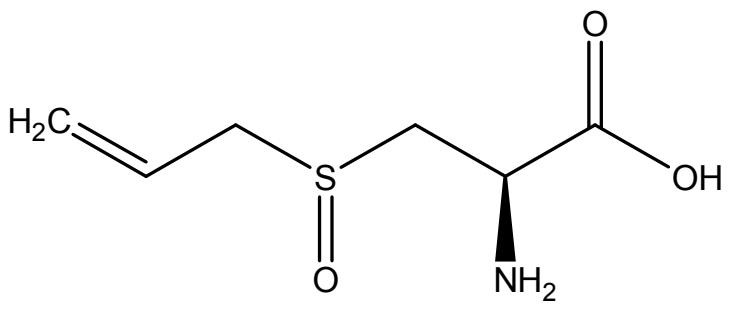

Figure 1: Chemical structure of Alliin

\section{EXPERIMENTAL}

\section{Material}

The raw garlic samples were collected from Jining (Shandong), China and Indore (M.P.) in India which is very well known places for the production of good quality of garlic and the tablet samples from the market. Material to be studied was identified by Dr. Mohammed Yusuf, Field taxonomist, Medicinal Plant Collection and Survey Unit, Department of Pharmacognosy, College of Pharmacy, King Saud University, Saudi Arabia. Specimens of the studied material were deposited in the herbarium, Department of Pharmacognosy, College of Pharmacy, King Saud University, Saudi Arabia.

\section{Apparatus and reagents}

Standard alliin (HPLC grade) was obtained from Sigma-Aldrich (CAS Number 17795 - 26- 5). Reagents and solvents of analytical grade (Ethyl acetate, $\mathrm{n}$ - hexane, ninhydrin etc.) were purchased from Fluka Chemicals (Busch, Switzerland) and Across Organics (Hamilton, $\mathrm{NJ}$ ), respectively. Pre-coated HPTLC glass plates of silica gel $60 \mathrm{~F} 254$ were purchased (E. Merck, Darmstadt, Germany). The application of standard and the extracts were made on HPTLC plate band wise with the help of CAMAG automatic TLC sampler-4 and developed in automatic development chamber-II (CAMAG, Muttenz, Switzerland). Scanning and documentation of developed HPLTLC plate were done by CATS 4 and CAMAG TLC Reprostar 3, respectively. A standard stock solution of alliin (1 $\mathrm{mg} / \mathrm{mL}$ ) was prepared by dissolving $10 \mathrm{mg}$ of standard in $10 \mathrm{~mL}$ dichloromethane. One milliliter of the stock solutions was again diluted to $9 \mathrm{~mL}$ of dichloromethane to get the concentration of $100 \mu \mathrm{gmL}^{-1}$. For making calibration graph, 2 - 16 $\mu \mathrm{L}$ of the standard solution was applied to HPTLC plate to provide concentration range of 200 - 1600 ngband $^{-1}$.

\section{Sample preparation}

Fresh garlic samples were weighed and dried in the sun. Dried garlic samples of $465 \mathrm{mg}$ and 320 $\mathrm{mg}$ of Chinese and Indian garlic, respectively were powdered and extraction was made with 10 $\mathrm{ml}$ of dichloromethane by vigorous stirring for 30 $\mathrm{s}$. The extraction procedure was repeated twice. Similarly, one tablet from each brand was weighed [Avg Wt. $603 \mathrm{mg}$ (US) and $550 \mathrm{mg}$ (UK)], crushed and extracted twice with the similar procedure. All the four extracts were dried by vacuum evaporation of the solvent and percentage yield was calculated. Dried extracts from each sample was dissolved in $10 \mathrm{ml}$ of dichloromethane and filtered through a $0.45 \mu \mathrm{m}$ filter membrane to make a stock solution for HPTLC analysis. One $\mathrm{ml}$ of this stock solution was mixed with $9 \mathrm{ml}$ of dichloromethane to perform the analysis. After optimizing the method, $2 \mu \mathrm{l}$ from all the four samples were applied for analyses. The samples were quantified against the standard alliin used for the calibration curve.

\section{Instrumentation and chromatographic conditions}

The analytical procedure was performed on HPTLC glass plates of size $20 \times 10 \mathrm{~cm}$ coated with silica gel 60F254 as the stationary phase. TLC Sampler 4 (Automatic) fitted with a Hamilton 
Gastight Syringe (1700 Series) of volume $25 \mu \mathrm{L}$ was used to apply the samples and standard on the HPTLC plate at an application speed of 160 $\mathrm{nl} / \mathrm{s}$. The development of spotted plate was done in a previously saturated automatic developing chamber with mobile phase n-hexane: ethyl acetate (29:1) moving in linear ascending mode.

After the development of HPTLC plate, it was air dried and sprayed with ninhydrin reagent. For further analyses, Camag TLC scanner IV was used to scan the developed and sprayed plate at $205 \mathrm{~nm}$ wavelength in absorbance mode by using the deuterium lamp. The slit dimensions were $4.00 \times 0.45 \mathrm{~mm}$ and the scanning speed was $20 \mathrm{~mm} / \mathrm{s}$.

\section{Preparation of calibration graphs}

Calibration graph for standard alliin was prepared by applying a series of spots of standard with eight different volumes so as to get a different amount of alliin per spot. They were prepared with respect to height and area versus amount per spot.

\section{Statistical analysis}

All the results are presented as mean \pm SEM. Comparative analysis of the results for each parameter was performed using SigmaStat $\AA$ for Windows, Systat Software Inc (San Jose, CA). One-way analysis of variance (ANOVA) was used to determine significant differences between the results at $p<0.05$.

\section{Method development}

The chromatogram was developed for alliin by selecting the mobile phase after trying several combinations of solvents (Figure 2). After optimization, the best resolution was observed in the selected mobile phase [nhexane:ethylacetate (29:1)]. A similar mobile phase has been employed for the resolution of dichloromethane extracts of samples S1 (CG), S2 (IG), S3 (USA), and S4 (UK). The optimum saturation time was $20 \mathrm{~min}$. The scanning of the plate and densitometric quantification was done at an optimized wavelength of $205 \mathrm{~nm}$ in absorbance mode.

\section{Method validation}

The validation of proposed method was executed as per the guidelines suggested by $\mathrm{ICH}$ and the linearity, precision, accuracy, LOD, LOQ and robustness were the parameters considered for validation [28].

\section{Linearity range}

For determining the linearity range of standard alliin, a series of spots of different volumes $(2 \mu \mathrm{l}$ $-16 \mu \mathrm{l}$ ) were applied so as to get the $200-1600$ ng quantity of alliin per band. The graph was plotted between concentration and peak area for linearity. The data for linearity range was statistically treated with least square linear regression analysis.

\section{Accuracy}

Standard addition method was used to determine accuracy. The pre-analyzed sample of alliin (300 $\mathrm{ng} / \mathrm{spot}$ ) was spiked with the extra 0,50, 100 and $150 \%$ of alliin and the solutions were reanalyzed in six replicates by the proposed. The \% recovery and percent relative standard deviation ( $\%$ RSD) were calculated.

\section{Precision}

The concentration levels of 150,300 and 600 $\mathrm{ng} / \mathrm{spot}$ of alliin was used to evaluate the precision of the proposed method by replicate analyses $(n=6)$. Inter-day precision was determined by repeating the intra-day assay on three different days.

\section{Robustness}

The robustness of the proposed method was evaluated in triplicate at 500 ngband $^{-1}$ by introducing some deliberate changes to the composition of mobile phase, the volume of mobile phase and duration of saturation. The results were evaluated in terms of relative standard deviation (RSD \%) and standard error of peak areas. Mobile phases prepared from nhexane: ethyl acetate in different proportions $(28: 2, v / v ; 30: 1, v / v ; 29: 2, v / v ; 28: 1, v / v)$ were used for chromatography. The change in mobile phase volume and duration of saturation was made by $20 \pm 2 \mathrm{~mL}(18,20$, and $22 \mathrm{~mL})$ and $20 \pm$ $10 \mathrm{~min}(10,20$, and $30 \mathrm{~min})$, respectively.

\section{LOD and LOQ}

The calculation of LOD and LOQ was made on the basis of standard deviation (SD) of the response and the slope (s) of the calibration graph using formulae [LOD $=3.3(\mathrm{SD} / \mathrm{S})$ and $\mathrm{LOQ}=10(\mathrm{SD} / \mathrm{S})]$.

\section{Assay of alliin}

Standard alliin and test samples ( $2 \mu \mathrm{l}$ each) were spotted on HPTLC plates. The percentage of alliin present in test samples (S1 to S4) was determined by measuring the area for the 
standard and test samples. Thereby the percentage of alliin was calculated for all the four samples and reported in Table 5.

\section{RESULTS}

The relation between the concentration of alliin and the corresponding peak area was linear within the range of 200 to $1600 \mathrm{ng} / \mathrm{spot}$. The linear regression analyses data for the calibration plot showed a good linear relationship with $r^{2}=$ 0.996 with respect to the area in the concentration range of $200-1600 \mathrm{ng}$. The regression equation for standard alliin was found to be $Y=1.792 x+182.855$. The precision values $(\mathrm{n}=6)$ for alliin were found $2.15-2.65 \%$ and $1.02-1.32 \%$, respectively, for inter-day and intra-day evaluation. Accuracy data in terms of $\%$ RSD was 0.99 - 1.06 and recovery 98.2 - 99.1 $\%$. The statistical data supports the selectiveness, precision, and accuracy of the proposed method. Therefore, the developed method can be recommended for routine analysis of garlic and its products for alliin contents.

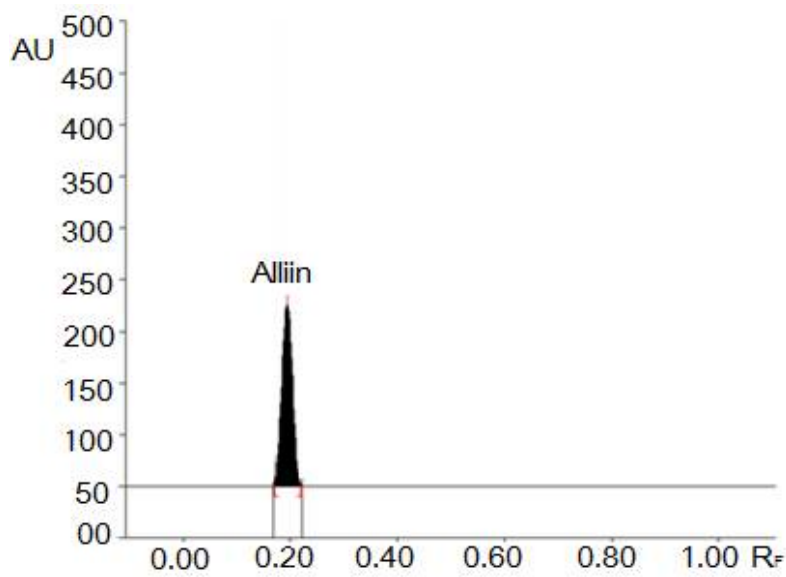

Figure 2: Chromatogram of standard alliin 1600 ng/spot @205nm

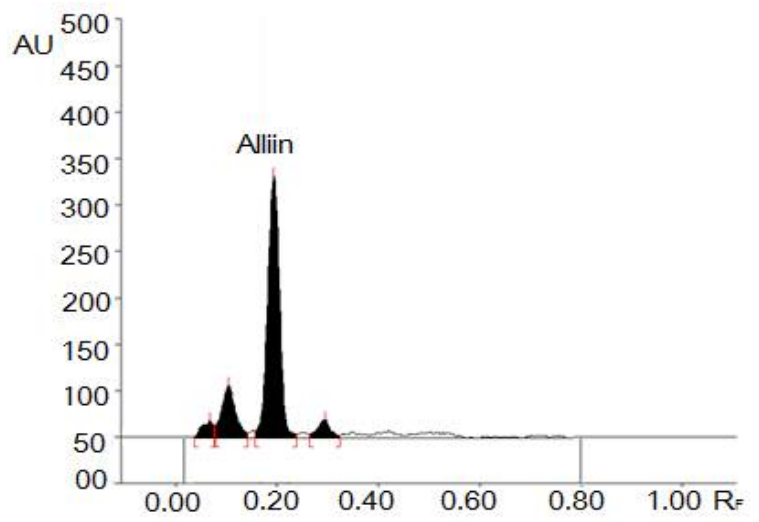

Figure 3: Chromatogram of Sample 1(CG) @ 205nm

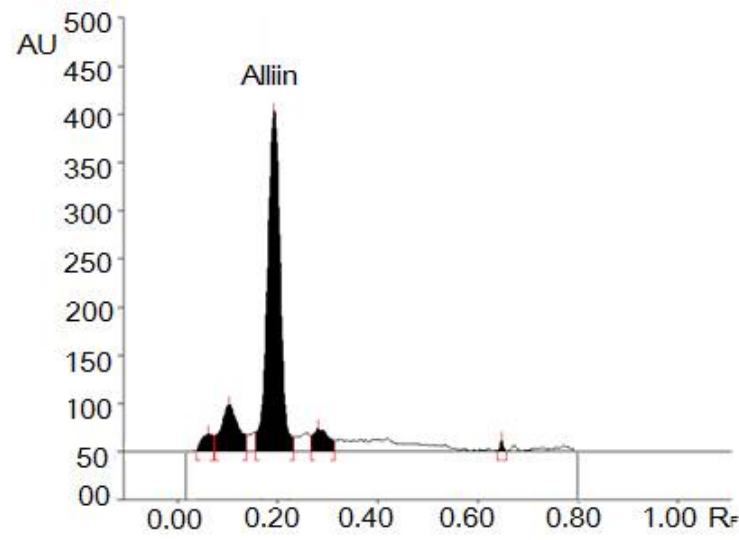

Figure 4: Chromatogram of Sample 2(IG) @ 205 nm

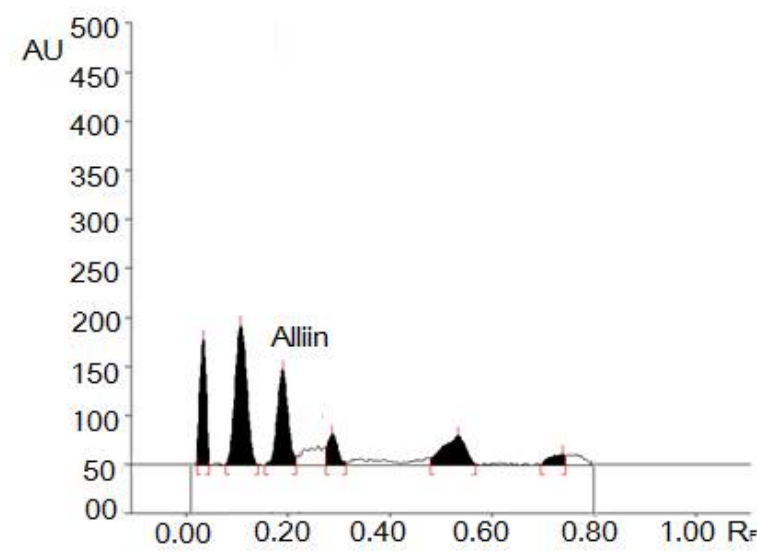

Figure 5: Chromatogram of Sample 3(USA) @ 205 $\mathrm{nm}$

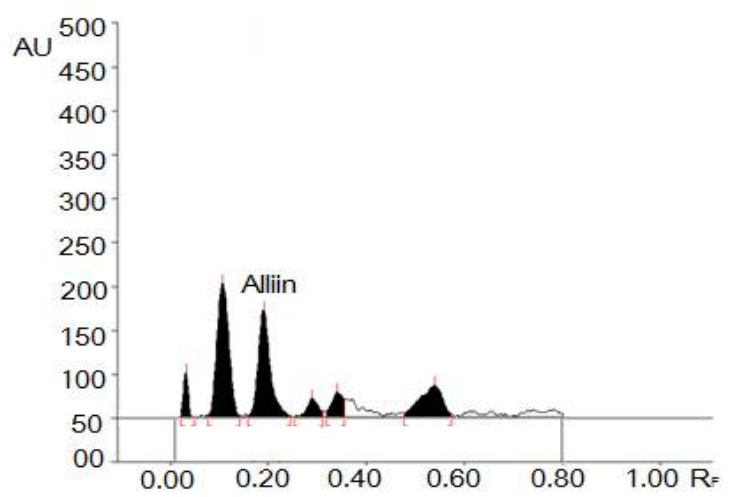

Figure 6: Chromatogram of sample 4(UK) @ 205 nm

The suggested method was efficient in separating constituents present in the samples (S1 to S4) and exhibiting sharp peaks of standard (alliin) with the selected mobile phase under chamber saturation conditions at a wavelength of $205 \mathrm{~nm}$ in absorbance mode. The mobile phase $n$ - hexane:ethyl acetate $(29: 1 \mathrm{v} / \mathrm{v})$ was found to furnish a sharp peak of alliin at $\mathrm{Rf}$ values $0.19 \pm 0.01$ (Figure 2). The developed method was found to be quite selective with good baseline resolution. 
Table 1: $R_{f}$, Linear regression data for the calibration graph and sensitivity parameters for alliin $(n=6)$

\begin{tabular}{lc}
\hline Parameter & Alliin \\
\hline $\mathrm{R}_{\mathrm{f}}$ & $0.19 \pm 0.01$ \\
Linear range (ng/band) & $100-800$ \\
Regression equation & $\mathrm{Y}=1.792 \mathrm{x}+182.855$ \\
Correlation coefficient $\left(\mathrm{r}^{2}\right)$ & 0.996 \\
Slope $\pm \mathrm{SD}$ & $1.792 \pm 0.05$ \\
Intercept $\pm \mathrm{SD}$ & $182.855 \pm 3.22$ \\
Standard error of Slope & 0.031 \\
Standard error of Intercept & 2.16 \\
LOD (ng/band) & 40.42 \\
LOQ (ng/band) & 111.72 \\
\hline
\end{tabular}

The calibration curve for alliin was linear in the range of 200 - $1600 \mathrm{ng} / \mathrm{spot}$ and a good linear relationship was verified by linear regression data for the plot (Table 1). The correlation coefficient $\left(r^{2}\right)$ for alliin was 0.996 and found to be significant $(p<0.05)$. The linear regression equation was $Y=1.792 x+182.855$ where $Y$ is a response and $X$ is the quantity of reference standard. The accuracy was determined by recovery analysis which afforded recovery of 98.20 - $99.10 \%$, and the different values are listed in Table 2. Low values of RSD 0.99 - 1.06 $\%$ indicated the excellent accuracy of the proposed method. RSD was in the range 1.02 $1.32,2.15-2.65 \%$, respectively for intra-day and inter-day precision which indicated good precision of the proposed method (Table 3).

The observations of robustness are shown in Table 4. Low values of RSD (0.325 - $0.439 \%)$ proved the robustness of the proposed HPTLC method. LOD \& LOQ (Table I) of the proposed method were found to be $40.42,111.72 \mathrm{ng} / \mathrm{spot}$ which suggested that the proposed method might be used in a broad range for detection and quantification of alliin.

\section{Alliin content of prepared samples}

The proposed method was exploited in the quantification of alliin in samples S1 (Figure 3), S2 (Figure 4), S3 (Figure 5) and S4 (Figure 6). Despite applying the same volume the peak size and area of a chromatogram of the sample, S2 was found to be highest in all the samples analyzed.

The quantity of alliin was found to be 24.568 $\mathrm{mg} / \mathrm{g}$ and $31.25 \mathrm{mg} / \mathrm{g}$ of dried powder of Chinese (S1) and Indian garlic (S2) respectively. The Alliin content in two tablet samples of U.S.A. (S3) and U.K. (S4) possess 7.11 and $8.83 \mathrm{mg} / \mathrm{Tab}$, respectively. The content of alliin evaluated in the different samples is given in Table 5.

Table 1: $R_{f}$, Linear regression data for the calibration graph and sensitivity parameters for alliin $(n=6)$

\begin{tabular}{lc}
\hline Parameter & Alliin \\
\hline $\mathrm{R}_{\mathrm{f}}$ & $0.19 \pm 0.01$ \\
Linear range (ng/band) & $100-800$ \\
Regression equation & $\mathrm{Y}=1.792 \mathrm{x}+182.855$ \\
Correlation coefficient $\left(\mathrm{r}^{2}\right)$ & 0.996 \\
Slope $\pm \mathrm{SD}$ & $1.792 \pm 0.05$ \\
Intercept $\pm \mathrm{SD}$ & $182.855 \pm 3.22$ \\
Standard error of Slope & 0.031 \\
Standard error of Intercept & 2.16 \\
LOD (ng/band) & 40.42 \\
LOQ (ng/band) & 111.72 \\
\hline
\end{tabular}

Table 2: Accuracy of the proposed method $(n=6)$

\begin{tabular}{lcccc}
\hline $\begin{array}{l}\text { Excess drug added to } \\
\text { analyte (\%) }\end{array}$ & Theoretical conc. (ng) & $\begin{array}{c}\text { Experimental } \\
\text { conc. (ng) }\end{array}$ & Recovery (\%) & RSD (\%) \\
\hline 0 & 300 & $295.3 \pm 3.21$ & 98.2 & 1.06 \\
50 & 450 & $443.8 \pm 4.58$ & 98.6 & 1.02 \\
100 & 600 & $593.1 \pm 5.96$ & 98.8 & 1.00 \\
150 & 750 & $742.2 \pm 7.42$ & 99.1 & 0.99 \\
\hline
\end{tabular}

Table 3: Precision of the proposed method

\begin{tabular}{ccccc}
\hline & \multicolumn{2}{c}{ Intraday Precision (Repeatability) $\mathrm{n}=6)$} & \multicolumn{2}{c}{ Interday Precision $(\mathrm{n}=6)$} \\
\hline Conc. (ngband ${ }^{-1}$ ) & Avg. Conc..SD & RSD (\%) & Avg. Conc..SD & RSD (\%) \\
\hline 150 & $149.23 \pm 1.98$ & 1.32 & $152.15 \pm 4.04$ & 2.65 \\
300 & $299.14 \pm 2.06$ & 1.21 & $301.19 \pm 6.89$ & 2.29 \\
600 & $600.18 \pm 6.07$ & 1.02 & $601.22 \pm 12.93$ & 2.15 \\
\hline
\end{tabular}

Table 4: Robustness of the proposed method

\begin{tabular}{lccc}
\hline Optimized conditions & Intentional changes in optimized conditions & \multicolumn{2}{c}{ Alliin } \\
\cline { 3 - 4 } & & SD & RSD (\%) \\
\hline Mobile phase & $n$-Hexane:ethylacetate $(29: 1 \mathrm{v} / \mathrm{v})$ & 2.18 & 0.439 \\
Composition & $(28: 2, \mathrm{v} / \mathrm{v} ; 30: 1, \mathrm{v} / \mathrm{v} ; 29: 2, \mathrm{v} / \mathrm{v} ; 28: 1, \mathrm{v} / \mathrm{v})$ & & \\
Mobile phase volume & $(18,20$, and $22 \mathrm{~mL})$ & 1.65 & 0.325 \\
Duration of saturation & $(10,20$, and $30 \mathrm{~min})$ & 2.06 & 0.412 \\
\hline
\end{tabular}


Table 5: Alliin content of four samples of garlic-

\begin{tabular}{|c|c|c|c|c|c|}
\hline $\begin{array}{l}\text { Sample } \\
\text { code }\end{array}$ & $\begin{array}{c}\text { Garlic } \\
\text { sample }\end{array}$ & $\begin{array}{c}\text { Mean wt. of } \\
\text { material }\end{array}$ & $\begin{array}{l}\text { Mean wt. } \\
\text { of extract }\end{array}$ & Alliin content & $\begin{array}{c}\text { Probable } \\
\text { allicin content }\end{array}$ \\
\hline S1(CG) & $\begin{array}{l}\text { Chinese } \\
\text { Garlic }\end{array}$ & $\begin{array}{l}465 \pm 0.05 \mathrm{mg} \\
\text { (Dried powder) }\end{array}$ & $2.13 \mathrm{mg}$ & $\begin{array}{l}24.568 \pm 0.002 \\
\mathrm{mg} / \mathrm{g} \text { of dried } \\
\text { material }\end{array}$ & $\begin{array}{c}8.19 \mathrm{mg} / \mathrm{g} \text { of } \\
\text { dried material }\end{array}$ \\
\hline S2 (IG) & $\begin{array}{l}\text { Indian } \\
\text { Garlic }\end{array}$ & $\begin{array}{l}320 \pm 0.02 \mathrm{mg} \\
\text { (Dried powder) }\end{array}$ & $2.03 \mathrm{mg}$ & $\begin{array}{c}31.25 \pm 0.004 \\
\mathrm{mg} / \mathrm{g} \text { of dried } \\
\text { material }\end{array}$ & $\begin{array}{l}10.08 \mathrm{mg} / \mathrm{g} \text { of } \\
\text { dried material }\end{array}$ \\
\hline S3(USA) & $\begin{array}{l}\text { Tablets } \\
\text { (USA) }\end{array}$ & $\begin{array}{l}602 \pm 1.13 \mathrm{mg} \\
(1 \mathrm{Tab})\end{array}$ & $49.62 \mathrm{mg}$ & $7.11 \pm 0.02 \mathrm{mg} / \mathrm{tab}$ & $2.37 \mathrm{mg} / \mathrm{tab}$ \\
\hline S4(UK) & $\begin{array}{l}\text { Tablets } \\
\text { (UK) }\end{array}$ & $\begin{array}{l}540 \pm 1.02 \mathrm{mg} \\
(1 \mathrm{Tab})\end{array}$ & $74.02 \mathrm{mg}$ & $8.83 \pm 0.03 \mathrm{mg} / \mathrm{tab}$ & $2.94 \mathrm{mg} / \mathrm{tab}$ \\
\hline
\end{tabular}

\section{DISCUSSION}

Garlic is an integral part of our daily diet and one of the most useful functional foods in the world. Unfortunately the methods of handling the garlic directly affect its therapeutic ability. Most of the garlic products do not indicate the actual amount of active ingredients supposed to be released from the preparation. This is one of the reasons why we need a simple and sensitive method for routine analysis of quality of garlic and its products. Till now many methods for the quantitative analysis of alliin was proposed but all these methods are complex and usually have an indirect determination of alliin or allicin.

The findings of present study offer a simple and direct method of quantification of alliin which is a relevant marker for quality control of garlic and garlic products. The statistical data for precision, specificity, sensitivity, and accuracy support the recommendation of this method for routine assessment of garlic and its preparation. Though allicin is medicinally more valuable than alliin but it is highly unstable compound, and no measurable quantity of allicin is present in whole garlic cloves. Therefore, quantification of alliin in garlic preparations justify the way of standardization of herbal products as well as raw garlic. The results of this experiment strongly support that the recommended dose of garlic tablets considered in this analyses possess enough amount of alliin (as recommended by WHO) being taken for a healthy heart [7]. As far as alliin contents are concerned the dried raw garlic appears as a better option than marketed garlic products but needs to be careful with the low release of allicin from alliin at acidic $\mathrm{pH}$.

\section{CONCLUSION}

The findings demonstrate that Indian garlic sample possesses slightly higher concentration of alliin than Chinese garlic. The marketed products usually do not indicate the concentration of active ingredients, a method for quantifying alliin in marketed garlic products has been developed. The garlic products evaluated contain the therapeutically required amount of alliin in prescribed serving size of the formulations. Thus, the proposed method can be used for routine analysis and standardization of raw garlic as well as garlic products for alliin contents.

\section{DECLARATIONS}

\section{Acknowledgement}

The authors would like to extend their sincere thanks and appreciation to the Deanship of Scientific Research at King Saud University for funding this research through Research Group Project no. RGP-073.

\section{Conflict of Interest}

No conflict of interest associated with this work.

\section{Contribution of Authors}

The authors declare that this work was done by the authors named in this article and all liabilities pertaining to claims relating to the content of this article will be borne by them.

\section{REFERENCES}

1. Campbell JH, Efendy JL, Smith NJ, Campbell GR. Molecular basis by which garlic suppresses atherosclerosis. J. Nutr. 2001; 131: 1006S-1009S.

2. Chanprame S, Kuo TM, Widholm JM. Soluble carbohydrate content of soybean (Glycine max L.) Merr. Somatic and zygotic embryos during development. In Vitro Cell Dev Bio. Plant. 1998; 34: 64-68.

3. Yeh YY, Liu L. Cholesterol-lowering effect on garlic extracts and organosulfur compounds: human and animal studies. J. Nutr. 2001; 131: 989S-993S.

4. Rahman K. Historical perspective on garlic and cardiovascular disease. J. Nutr. 2001; 131: 977S-979S. 
5. Hughes J, Trgova A, Tomsett AB, Jones MG, Cosstick R, Collin HA. Synthesis of the flavor precursor, alliin, in garlic tissue cultures. Phytochemistry 2005; 66(2): 187194.

6. Lawson LD. Garlic: a review of its medicinal effects and indicated active compounds. In: Lawson LS, Bauer R, Editors, Phytomedicines of Europe: Chemistry and Biological Activity, ACS Symposium Series 691, Am. Chem. Soc. Washington. 1998.

7. World Health Organization. WHO Monographs on medicinal plants commonly used in the Newly Independent States (NIS), WHO Press, Geneva. 2010.

8. American Dietetic Association. Position of the American Dietetic Association: functional foods. J Am Diet Assoc. 2004; 104(5): 814-826.

9. Ribak ME, Calvey EM, Harnly JM. Quantitative determination of allicin in garlic: supercritical fluid extraction and standard addition of allin. $J$ Agric Food Chem. 2004; 52(4): 682-687.

10. Silva EYY, Moretti CL, Mattos LM. Compostos funcionais presentes em bulbilhos de alhos armazenados sob refrigeração, provenientes de cultivos no Brasil e na China. Ciência Rural 2010; 40(12): 2580-2587.

11. Lawson LD, Wang ZYJ, Hugues BG. Identification and HPLC quantitation of the sulfides and dialk (en) $y l$ thiosulfinates in commercial garlic products. Plant Medicine 1991; 57(4): 363-370.

12. Holub BJ, Arnott K, Davis JP, Nagpurkar A, Peschell J. Organosulfur compounds from garlic. In J. Shi, G. Mazza \& M. L. Maguer (Eds.). Functional foods: biochemical and processing aspects. Washington; CRC Press. 2002.

13. William DM, Pant CM. Neem Biotech Ltd. Process for the production of allicin; 2007 (US 7179632 B2).

14. Ayyanar M, Sankarasivaraman K, Ignacimuthu $S$. Traditional herbal medicines used for the treatment of diabetes among two major tribal groups in South Tamil Nadu, India. Ethnobot. Leafl. 2008; 12: 276-280.

15. Lanzotti $V$. The analysis of onion and garlic. J Chromatogr A 2006; 1112(1-2): 3-22.
16. Kubec R, Svobodovà M, Velis̀ J. Gas chromatographic determination of $S$-alk(en)ylcysteine sulfoxides. $J$ Chromatogr A 1999; 862(1): 85-94.

17. Cunico RL, Gooding KM, Wehr T. Basic HPLC and CE of Biomolecules. Laboratory Richmond CA, 1998.

18. Rubinson KA, Rubinson JF. Contemporary Instrumental Analysis, 1st ed. Prentice-Hall, Inc, 1999.

19. Ichikawa $M$, Ide $N$, Yoshida J, Yamaguchi $H$, Ono $K$. Determination of seven organosulfur compounds in garlic. J Agric Food Chem. 2006; 54(5): 1535-1540.

20. Kanaki NS, Rajani M. Development and validation of a thin-layer chromatography-densitometric method for the quantitation of alliin from garlic (Allium sativum) and its formulations. Journal of AOAC International 2005; 88(5): 1568-1570.

21. Nasim SA, Mujib A, Rashmi K, Samar F, Junaid A, Mahmooduzzafar. Improved alliin yield in somatic embryos of Allium sativum L. (cv. Yamuna safed) as analyzed by HPTLC Acta Biol Hungarica 2009; 60(4): 441-454.

22. Nasim SA, Dhir B, Rashmi K, Samar F, Mahmooduzzafar, Mujib A. Alliin obtained from leaf extract of garlic grown under in situ conditions possess higher therapeutic potency as analyzed in alloxaninduced diabetic rats. Pharmaceut Biol 2011; 49(4): 416421.

23. Siddiqui NA, Alam P, Al-Rehaily AJ, Al-Oqail MM, Parvez MK. Simultaneous Quantification of Biomarkers Bergenin and Menisdaurin in the Methanol Extract of Aerial Parts of Flueggea virosa by Validated HPTLC Densitometric Method. J Chromatogr Sci. 2015; 53: 824829.

24. International Conference on Harmonization (ICH) of technical requirements for registration of pharmaceuticals for human use, harmonised triplicate guideline on validation of analytical procedures: Text and Methodology Q2 (R1), complementary guideline on methodology incorporated by the $\mathrm{ICH}$ steering committee, IFPMA, Geneva. 2005 